\title{
PERAN ULASAN DAN HARGA DALAM MENINGKATKAN PENJUALAN DI \\ MARKETPLACE.
}

\section{OLEH}

Ray Dwiki Syahputra

UIN Raden Intan Lampung

\begin{abstract}
Abastrak
The development of online shops in Indonesia is growing vey rapidly with a variety of available platfoms making producers compete to sell in the marketplace by providing various goods or services. This study aims to re-analyze relate consumer decsions in making purchases in the marketplace by looking at reviews and price. The method uses in reasearch is a qualitative method which is correlated with the type of literature study.
\end{abstract}

\section{A. LATAR BELAKANG}

Ekonomi merupakan salah satu ilmu yang mempelajari tentang bagaimana cara manusia memenuhi kebutuhan hidupnya, di tuntut untuk beraktifitas dan berkerja keras. islam pun mengajarkan manusia untuk melaksanakan ekonomi sesuai dengan konsep dalam ekonomi islam yaitu tijarah atau disebut dengan perniaga. Bentuk suatu kegiatan ekonomi atau perniagaan yang diajarkan oleh islam yang bertujuan untuk mendapatkan manfaat atas barang yang ditukar dengan barang lain.

Jual beli yaitu suatu transaksi tukar menukar barang yang mempunyai nilai dengan cara suka rela antara para pihak, pihak satu menerima benda dari pihak lain dengan ketentuan rukun dan syarat dalam jual beli yang sesuai dengan hukum islam yang melarang adanya transaksi jual beli barang yang dilarang atau haram.

Kemajuan teknologi memungkinkan untuk dilaksanakannya hubungan bisnis melalui internet yang membuat prubahan prilaku konsumen dari membeli secara offline yaitu dengan datang langsung pada sebuah toko yang dimana terdapat barang yang ingin dibeli menjadi membeli secara online. Bagi konsumen tanpa keluar rumah dan bersusah payah mencari alamat toko konsumen lebih memilih untuk melakukan belanja online karena selain lebih mudah di akses dalam situs jual beli online juga terdapat Jutaan 
plihan barang dan harga yang bervarian sehingga konsumen dapat leluasa memilih dan mencari barang yang dinginkan.

Penerapan tekonologi komunikasi informasi yang bisa digunakan untuk menunjang penjualan adalah E-commers, E-commers adalah penjualan atau perdagangan yang dilakukan melalui media elektronik. Secara definisi E-commers merupakan suatu aktifitas perniagaan seperti layaknya perniagaan atau perdagangan pada umumnya yang mana dalam E-commers transaksinya tidak bertemu secara fisik akan tetapi mereka berkomunikasi melalui salah satu aplikasi atau website dari E-commers.

Di Indoensia sendiri E-commers yang sedang mengalami perkembangan yang pesat yaitu Shopee, Shopee merupakan salah satu pendatang baru di Indonesia mulai Desember 2015, jika dibandingkan dengan situs belanja online lainnya. Shopee dengan marketplacenya dikenal prestasinya melalui promosi yang dalam waktu singkat pengguna Shopee tidak kalah banyak dari pesaingnya. Adapun keunggulan dari Shopee adalah Marketplace pertama bagi kosumen ke komsumen atau disebut dengan $\mathrm{C} 2 \mathrm{C}$ yang berani menawarkan gratis biaya kirim ke seluruh Indonesia tanpa minimal pembelian untuk produk yang bertanda khusus. Selaian memiliki sistem C2C Shopee juga menerapkan sistem B2B atau disebut dengan Business to Business. Shopee mengklaim bahwa ia merupakan marketplace dengan tempat belanja termurah dan memberikan garansi harga termurah khusus di Asia tenggara terutama Indonesia.

Dari sistem yang diterapkan oleh Shopee sendiri mengakibatkan banyaknya penjual yang berminat untuk membuka toko online di Shopee. Perkembangan baik dari bahan pangan, Fashion, Herbal, Produk kecantikan atau Skincare dan juga alat elektronik yang semakin meningkat hal ini lah yang menimbulkan munculnya inovasi-inovasi baru yang di ciptakan oleh Penjual untuk menjual barang baru yang lebih trendy dan inovasi. Penjual dengan kualitas produk dan pelayanan yang baik akan bertumbuh dengan pesat, dalam jangka panjang maka perusahaan tersebut akan berhasil bertahan dibandingkan dengan perushaan lainnya.

Dengan keadaan yang demikian maka penjual membutuhkan suatu strategi yang tepat dan berkelanjutan untuk menjangkau setiap pengunjung pada toko online dan dalam mempertahankan pangsa pasar, Perusahaan harus dapat memikirkan strategi pemasaran yang tepat dan tertarget. Dengan strategi yang tepat maka perusahaan dapat mencapai target pemasaran. Strategi pemasaran yang kurang tepat dapat menjadikan kelemahan bagi penjual dalam bersaing dengan penjual lainnya yang telah menerapkan strategi yang tepat dan matang. 
Dalam Marketplace peran Ulasan dan harga sangat berpengaruh dalam mencapai target penjualan. Jika penjual membuka toko baru maka di dalam toko tersebut belum ada penialaian atau ulasan dari pembeli, untuk mengatasi masalah ini penjual melakukan semcam trik untuk mendapatkan ulasan dengan cara melakukan pesanan palsu (fake order) disisi lain foto produk dan juga iklan akan sangat berpengaruh pada minat beli di Shopee, karena di dalam marketplace pembeli hanya dapat melihat foto produk yang ingin dibeli tanpa bisa melihatnya secara langsung.

Selain dari ulasan dan harga didalam Marketplace juga menyediakan fitur iklan, iklan adalah bentuk komunikasi nonpribadi yang dilakukan penjual untuk menginformasikan, mendidik, atau membujuk pasar sasaran. Iklan sebaiknya digunakan untuk menjangkau sasaran yang luas, menciptakan brand awardness menjadi sarana pembeda antar penjual dan produk dengan pesaing.

Iklan di internet bisa merupakan iklan yang pasif (hanya dapat dilihat) atau juga dapat interaktif. Interaksi dapat dilakukan secara online dengan menggunakan chatting dan layanan call center atau dengan menggunakan web dan email. Salah satu keuntungan web adalah kemampuanny memberikan berbagai tipe pilihan interaktif dengan biaya yang rendah dan wajar (tidak mahal). Pengiklan atau agen priklanan biasanya menargetkan kelompok kosumen atau calon pembeli yang menjanjikan. Kategorisasi kelompok target ini dapat dibuat berdasarkan pertimbangan latas belakang geografis, demografis dan psikologis.

Dari penjabaran latar belakang tersebut maka peneliti tertarik untuk melakukan penelitian yang berjudul " PERAN ULASAN DAN HARGA DALAM MENINGKATKAN PENJUALAN DI MARKETPLACE "

\section{A. RUMUSAN MASALAH}

1. Bagaimana pengaruh ulasan untuk meningkatkan penjualan didalam marketplace?

2. Bagaimana peran harga dalam mempengaruhi minat beli konsumen didalam marketpalce

\section{B. TUJUAN PENULISAN}

1. Untuk mengetahui seperti apa pengaruh ulasan dalam meningkatkan penjualan.

2. Untuk mengetahui seperti apa peran harga untuk mempengaruhi minat beli didalam marketplace.

\section{MODEL HUBUNGAN VARIABEL}

1. Model hubungan antara variabel sederhana : 
Hubungan variabel ini terdiri dari satu (1) variabel independen dan dependen. Hal ini dapat digambarkan seperti gambar berikut. Berdasarkan paradigma tersebut, maka kita dapat menentukan:

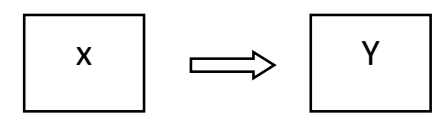

$\mathrm{X}=$ Strategi Marketing

Y = Terhadap Penjualan di Situs Jual Beli Online Shopee

2. Model sederhana berurutan :

Yakni paradigma yang terdiri dari lebih dari dua variabel, namun mempunyai hubungan yang masih sederhana. Perhatikan gambar berikut:

$\mathrm{X} 1=$ Ulasan

$\mathrm{X} 2=$ Harga

3. Model ganda dua variabel berurutan :

Yaitu paradigma yang mempunyai dua (2) variabel independen dan satu (1) dependen. Dalam paradigma ini terdapat 3 rumusan masalah deskriptif dan 4 rumusan masalah asosiatif (3 korelasi sederhana dan 1 korelasi ganda).

\section{PEMBAHASAN}

1. Ulasan

Menurut Mo, el, al. Dalam saripa (2019) berpendapat bahwa ulasan berisikan tentang gambar yang mencerminkan kualitas barang yang sebenarnya, seperti masalah warna, spesifikasi tidak konsisten, masalah penggunaan atau kualitas tinggim dan pengalaman yang baik. Ulasan sendiri merupakan feedback yang diberikan oleh konsumen atau pelanggan pada produk yang sudah di beli atau sebagai salah satu bentuk dari electronic word of mouth yang digunakan sebagai media untuk konsumen bisa mempunyai review baik berupa saran, kritik, maupun segala hal yang diinginkan mengenai produk atau jasa yang akan dibeli, dari informasi tersebut dapat digunakan untuk konsumen dalam mencari informasi.

Moe dan Schwidel, (2012), menguhubungkan antara rating terhadap tingkat pengambilan keputusan pelanggan, pengaruh penilaian pelanggan terhadap rating sebelum memutuskan untuk membeli sesuatu terganti pada seberapa sering rating atau penilaian atau ulasan dilakukan pelanggan pada suatu produk. 
Lackermair et al., (2013) dalam ulasan produk terdapat empat indikator yang dapat menggambarkan kelebihan atau kelemahan sebuah produk, yaitu :

a) Awarensess (kesadaran)

Pelanggan sebuah E-commerce kesadaran mengenai fitur ulasan produk oleh pelanggan lain, dimana informasi tersebut dapat digunakan untuk proses seleksi produk.

b) Frequency (frekuensi)

Dalam dimensi ini menilai perilaku konsumen dalam penggunaan fitur ulasan produk sebagai sumber informasi mereka dalam proses pembelian. Frekuensi diukur dari seberapa sering pelanggan menggunakan fitur ulasan produk di marketplace atau platfom lainnya.

c) Comparison (perbandingan)

Dalam proses pengambilan keputusan pembeli mengalami sebuah tahap membandingkan beberapa produk. Begitu juga dengan ulasan produk oleh pelanggan lain. Untuk menentukan kualitas sebuah produk, pelanggan dapat melakukan perbandingan ulasan.

d) Effect (pengaruh)

Setelah pelanggan memiliki kesadaran akan fitur ulasan produk dan melakukan perbandingan, maka akan diperoleh sebuah pengaruh terhadap penyeleksian produk untuk menagmbil keputusan pembelian.

Dari penjelasan di atas maka ulasan atau rating sangat berpengaruh dalam konsumen untuk pengambilan keputusan untuk membeli suatu produk didalam marketpalce, semakin baik atau semakin tinggi rating ulasan di dalam marketplace maka akan semakin mudah bagi penjual untuk membuat pelanggan percaya yang kemudian melakukan pembelian.

2. Harga

Harga dapat dijelaskan sebagai sejumblah nilai uang atau nilai yang ditukarkan untuk mendapatkan jasa atau barang guna mendapatkan manfaat dari mengggunakan atau memiliki produk tersebut. Untuk dapat menjadi sukses dalam memasarkan suatu barang atau jasa, setiap perusahaan harus menetapkan harganya secara tepat. Harga merupakakan satu-satunya unsur marketing mix yang memberikan pemasukan atau pendapatan bagi perusahaan, sedangkan ketiga unsur lainnya (produksi, promosi dan distribusi) menyebabkan timbulnya biata pengeluaran. Harga sangat penting karena menentukan keuntungan dan kelangsungan hidup perusahaan. Penentuan harga memiliki 
dampak pada penyesuaian strategi pemasaran yang diambil elastisitas harga dari suatu produk juga akan mempengaruhi permintaan dan penjualan., Terdapat tiga indikator harga diantaranya :

1) Kelayakan harga

Produk yang dibeli dari marketplace memiliki harga yang layak atau pantas

2) Kesesuaian harga dengan kualitas produk

Harga produk yang dibeli di marketplace haruslah sesuai dengan kualitas produk yang ada dan sebenarnya.

3) adanya discount atau potongan harga

didalam marketplace pembeli bisa mendapatkan potongan harga apabila pembeli membeli dengan kuantitas tertentu.

Menurut Husein 2015 dalam (Agustinawati, 2016 : 3) harga merupakan sesuatu yang sangat penting untuk dipertimbangkan oleh pembeli untuk memutuskan atau tidak membeli terhadap barang yang dibutuhkan. Pada dasarnya ada empat jenis tujuan penetapan harga, yaitu :

a. Tujuan berorientasi pada laba

Asumsi teori ekonomi klasik menyatakn bahwa setiap perusahaan selalu memilih harga yang dapat menghasilkan laba paling tinggi. Tujuan ini dikenal dengan istilah maksimisasi laba.

b. Tujuan berorientasi pada volume

Selain berorientasi pada laba, ada pula perusahaan yang menetapkan harganya berdasarkan tujuan yang berorientasi pada volme tertentu yang biasa dikenal dengan istilah volume pricing objective.

c. Tujuan berorientasi pada citra

Citra suatu perusahaan dapat dibentuk dengan strategi penetapan harga. Perusahaan dapat menetapkan harga tinggi untuk membentuk atau mempertahankan citra prestisius. Sementara itu harga rendah dapat digunakan untuk membentuk citra nilai tertentu, misalnya memberikan jaminan bahwa harga adalah harga terendah dalam suatu wilayah.

d. Tujuan stabilisasi harga

Dalam pasar yang konsumennya sangat sensitive terhadap harga, bila suatu perusahaan menurunkan harganya, maka para pesaing harus menurunkan pula harga mereka.

Harga memiliki dua peranan utama dalam proses pengambilan keputusan para pembeli, yaitu peranan alokasi dan peranan informasi (Tjiptono, 2008) : 
a. Peranan alokasi dari harga, yaitu fungsi harga dalam membantu para pembeli untuk memutuskan cara memperoleh manfaat atau utilitas tertinggi yang diharapkan berdasarkan daya belinya. Dengan demikian, adanya harga dapat membantu para pembeli untuk memutuskan cara mengalokasikan daya belinya pada berbagai jenis barang dan jasa. Pembeli membandingkan harga dari berbagai alternatif yang tersedia, kemudian memutuskan alokasi dana yang dikehendaki.

b. Peranan informasi dari harga, yaitu fungsi harga dalam 'mendidik' konsumen mengenai faktor-faktor produk, seperti kualitas. Hal ini terutama bermanfaat dalam situasi dimana pembeli mengalami kesulitan untuk menilai faktor atau manfaatnya secara objektif. Persepsi yang sering berlaku adalah bahwa harga yang mahal mencerminkan kualitas yang tinggi dari suatu barang.

Harga merupakan salah satu faktor penentu pembeli dalam menentukan suatu keputusan pembelian terhadap suatu produk maupun jasa. Apalagi apabila produk atau jasa yang akan dibeli tersebut merupakan kebutuhan sehari-hari seperti makanan, minuman dan kebutuhan pokok lainnya, pembeli akan sangat memperhatikan harganya. Pengusaha perlu untuk memperhatikan hal ini, karena dalam persaingan usaha, harga yang ditawarkan oleh pesaing bisa lebih rendah dengan kualitas yang sama atau bahkan dengan kualitas yang lebih baik. Sehingga dalam penentuan harga produk atau jasa yang dijual, baik perusahaan besar maupun usaha kecil sekalipun harus memperhatikan pembelinya dan para pesaingnya.

\section{PENUTUP}

A. Kesimpulan

Ulasan sangat berpengaruh dalam konsumen untuk pengambilan keputusan untuk membeli suatu produk didalam marketpalce, semakin baik atau semakin tinggi rating ulasan di dalam marketplace maka akan semakin mudah bagi penjual untuk membuat pelanggan percaya yang kemudian melakukan pembelian.

Lackermair et al., (2013) dalam ulasan produk terdapat empat indikator yang dapat menggambarkan kelebihan atau kelemahan sebuah produk, yaitu :

a) Awarensess (kesadaran)

Pelanggan sebuah E-commerce kesadaran mengenai fitur ulasan produk oleh pelanggan lain, dimana informasi tersebut dapat digunakan untuk proses seleksi produk.

b) Frequency (frekuensi) 
Dalam dimensi ini menilai perilaku konsumen dalam penggunaan fitur ulasan produk sebagai sumber informasi mereka dalam proses pembelian. Frekuensi diukur dari seberapa sering pelanggan menggunakan fitur ulasan produk di marketplace atau platfom lainnya.

c) Comparison (perbandingan)

Dalam proses pengambilan keputusan pembeli mengalami sebuah tahap membandingkan beberapa produk. Begitu juga dengan ulasan produk oleh pelanggan lain. Untuk menentukan kualitas sebuah produk, pelanggan dapat melakukan perbandingan ulasan.

d) Effect (pengaruh)

Setelah pelanggan memiliki kesadaran akan fitur ulasan produk dan melakukan perbandingan, maka akan diperoleh sebuah pengaruh terhadap penyeleksian produk untuk menagmbil keputusan pembelian.

Harga merupakan salah satu faktor penentu pembeli dalam menentukan suatu keputusan pembelian terhadap suatu produk maupun jasa. Apalagi apabila produk atau jasa yang akan dibeli tersebut merupakan kebutuhan sehari-hari seperti makanan, minuman dan kebutuhan pokok lainnya, pembeli akan sangat memperhatikan harganya Terdapat tiga indikator harga diantaranya :

1) Kelayakan harga

Produk yang dibeli dari marketplace memiliki harga yang layak atau pantas

2) Kesesuaian harga dengan kualitas produk

Harga produk yang dibeli di marketplace haruslah sesuai dengan kualitas produk yang ada dan sebenarnya.

3) adanya discount atau potongan harga

didalam marketplace pembeli bisa mendapatkan potongan harga apabila pembeli membeli dengan kuantitas tertentu. 


\section{DATAR PUSTAKA}

Agustinawati. (2016). Pengaruh Citra Merek, Kualitas Produk, dan Harga Terhadap Keputusan Membeli Shampo Dove Di Kota Lhokseumawe. Jurnal Ilmu Dan Riset Manajemen, 5(juli), 1-11.

Antonius, I., Sugiono, D., Pemasaran, J. M., Petra, U. K., \& Siwalankerto, J. (2013). 668-1181-1-Sm. $1(2), 1-11$.

Arbaini, P. (2020). Pengaruh Consumer Online Rating Dan Review Terhadap Keputusan Pembelian Pada Pengguna Marketplace Tokopedia. Jurnal Bisnis Dan Manajemen, 7(1), 25-33.

Firmansyah, G. (2019). Pengaruh Harga, Reputasi Vendor dan Ulasan Produk terhadap Keputusan Pembelian di Tokopedia (Studi pada Masyarakat Kabupaten Kebumen). STIE Putra Bangsa, $x$.

Ilmiyah, K., \& Krishernawan, I. (2020). Pengaruh Ulasan Produk, Kemudahan, Kepercayaan, Dan Harga Terhadap Keputusan Pembelian Pada Marketplace Shopee Di Mojokerto. Manajemen, 6 (1)(June), 3142 .

Lackermair, G., Kailer, D., \& Kanmaz, K. (2013). Importance of online product reviews from a consumer's perspective. Advances in Economics and Business, 1(1), 1-5.

Servanda, I. R. S., Reno Kemala Sari, P., \& Ananda, N. A. (2019). Peran Ulasan Produk Dan Fot Produk Yang Ditampilkan Penjual Pada Marketplace Shopee Terhadap Minat Beli Pria Dan Wanita. Jurnal Manajemen Dan Bisnis, 2(2), 69-79. https://doi.org/10.37673/jmb.v2i2.526

Sudjatmika, F. V. (2017). Pengaruh Harga, Ulasan Produk, Kemudahan, dan Keamanan Terhadap Keputusan Pembelian Secara Online di Tokopedia.com. Agora, 5(1), 1-7.

Villela, lucia maria aversa. (2013).. Journal of Chemical Information and Modeling, 53(9), 1689-1699. 